総説

\title{
マイクロ磁気デバイスと微細加工技術
}

\author{
山口 正洋，荒井 賢一 \\ 東北大学電気通信研究所, 宁980-77 仙台市青葉区片平2-1-1.
}

\section{Micromagnetic Devices Fabricated by Micromachining Techniques}

\author{
Masahiro Yamaguchi and Ken-Ichi Arai \\ Research Institute of Electrical Communication, Tohoku University, 2-1-1 Katahira Aoba-ku, Sendai 980-77.
}

Received August 25, 1995

\section{SYNOPSIS}

This article describes the recent remarks in the technology field of micromagnetic devices and micromagnetic actuators. The technology bases of these devices include material development, process technology, device design technology and high-density packaging technology. The fabrication techniques are most important for realizing these devices. LICA process andanodic oxidation process for thick metallic structure are explained.

\section{KEYWORDS}

micromagnetic devices, micromagnetic actuators, micromachining, skin depth, characteristic leng th.

\section{1 まえがき}

インダクタやトランスなどの磁心を薄膜化する研究 1)は1970年にSalehによって試みられ2)，その後, 1984 年の白江らの平面コイルの研究を端緒 ${ }^{32}$ として日本で 研究が本格化した、薄膜磁心では磁束を環流させるた めの閉磁路構造や巻線構造などの立体的構造が必要と なるため，様々な微細加工技術が導入されている，多 くの場合，数 $\mu \mathrm{m}$ ルールと比較的マクロな微細加工では

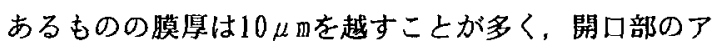
スペクト比が1を越す立体的加工技術が要求される．薄 膜磁心の用途亡して期待される分野は, 携帯機器用の マイクロ電源, 携帯機器用LCフィルタ, フラックスゲ 一トセンサ（倍周波形磁気変調器），MIGヘッド用集積 化巻線, 電磁型マイクロマシン駆動機構など, エネル ギー変掺から計測・情報処理まで多岐に渡っている。
筆者らは，このような薄膜磁心を始めとして磁気表面 弾性波素子，マイクロ磁気弾性素子，トンネルトラン ジスタなど, 集積化可能な静止形の薄膜磁気素子とバ ルク材料による平面形磁気素子を総称してマイク口磁 気デバイスと挐んでいる1-221.

一方, マイクロ磁気アクチュエータ (3)-36) は, マイ クロマシン分野におけるアクチュエータ開発への要求, とくに $\mu \mathrm{mオ}$ ーダの微細機構を持つミリサイズのマシン (ミリマシン)への関心の高まり，及び厚膜コイルの 微細加工技術の進展等によって，1993年初頭頃から活 発化している. マイクロマシンの駆動源としては従来 から静電力, 圧電力, 熱嗀張などが検討されているが, およそ凅サイズであれば，これらの従来方式より電磁 形の方が駆動力や変位を增大させることが可能で，実 用的なミリマシンを実現する上で有用性が高いと考え 
られている．また磁歪膜の応用も検討されている．期 待される用途には，光スキャナ・光フィルタ，マイク ロバルブ・マイクロリレー, マイクロモー夕（回転形， 直進形)などが挙げられている. ふつうシリコンマイ クロマシニングにより作製され，磁性体楧造はフレー ムめっき法による場合が多い。

微細加工法から見た場合，マイクロ磁気デバイスと マイクロ磁気アクチュエータはともに厚膜微細加工,

閉磁路構造 : 巻線構造の形成などの点で共通している. 本稿では，これらの研究開発の現状之微細加工法から 見た特徴を述べる.

\section{2 マイクロ磁気デバイスの枚要}

Fig. 1は薄膜磁心に関する主要技術とその内容をま とめたもので, マイクロ磁気デハイスやマイクロ磁気 アクチュエータ全般にも適用できる関係を示している. 磁性材料としては，およそ薄膜・厚膜化が可能なもの は何でも使用されるが，スパッ夕法による多元パーマ ロイ薄膜とCo基非晶質膜, めっき法によるパーマロイ
膜・Ni膜など，比較的容易に作製可能な材料がよく用 いられる，高周波用薄膜磁心では渦電流の抑制が主要 な問題になっており，高抵抗薄膜は開発が急速に進展 している. フェライトチップは, NiCuZnフェライトと $\mathrm{Ag}$ 系導体材料を交互にスクリーン印刷し， $900^{\circ} \mathrm{C}$ 前後で 焼成して得られる，導体材料はスパッ夕法とめっき法 ではCu或いはAu, フェライトチップではフェライト材 料之同時焼成が可能なAg系材料が使用されている. 絶 縁材料は基本的に磁性材料への相互拡散や応力などの 問題のない材料が選ばれる，厚膜構造では，スピンコ 一トなどにより数十 $\mu$ mの膜厚が得られるレジストやポ リイミドなどが使用さ扎る場合が多い、ポリイミドは 耐压が高い点も特徵である．LIGAプロセス（シンクロ トロン放射光による〜 $1 \mathrm{~mm}$ 厚膜微細加エプロセス）では PMMAも使用される.

プロセス上は，碰性薄膜は一般に難エッチング材料 に属し，反応性イオンエッチング（RIE）が適用困難な 点が特徴である. $\mathrm{CCl}_{4}$ ガスによるFeAISi膜の昇温RIEや， $\mathrm{C} 0+\mathrm{NH}_{3}$ ガスによる常温RIEなどが報告され始めているが,

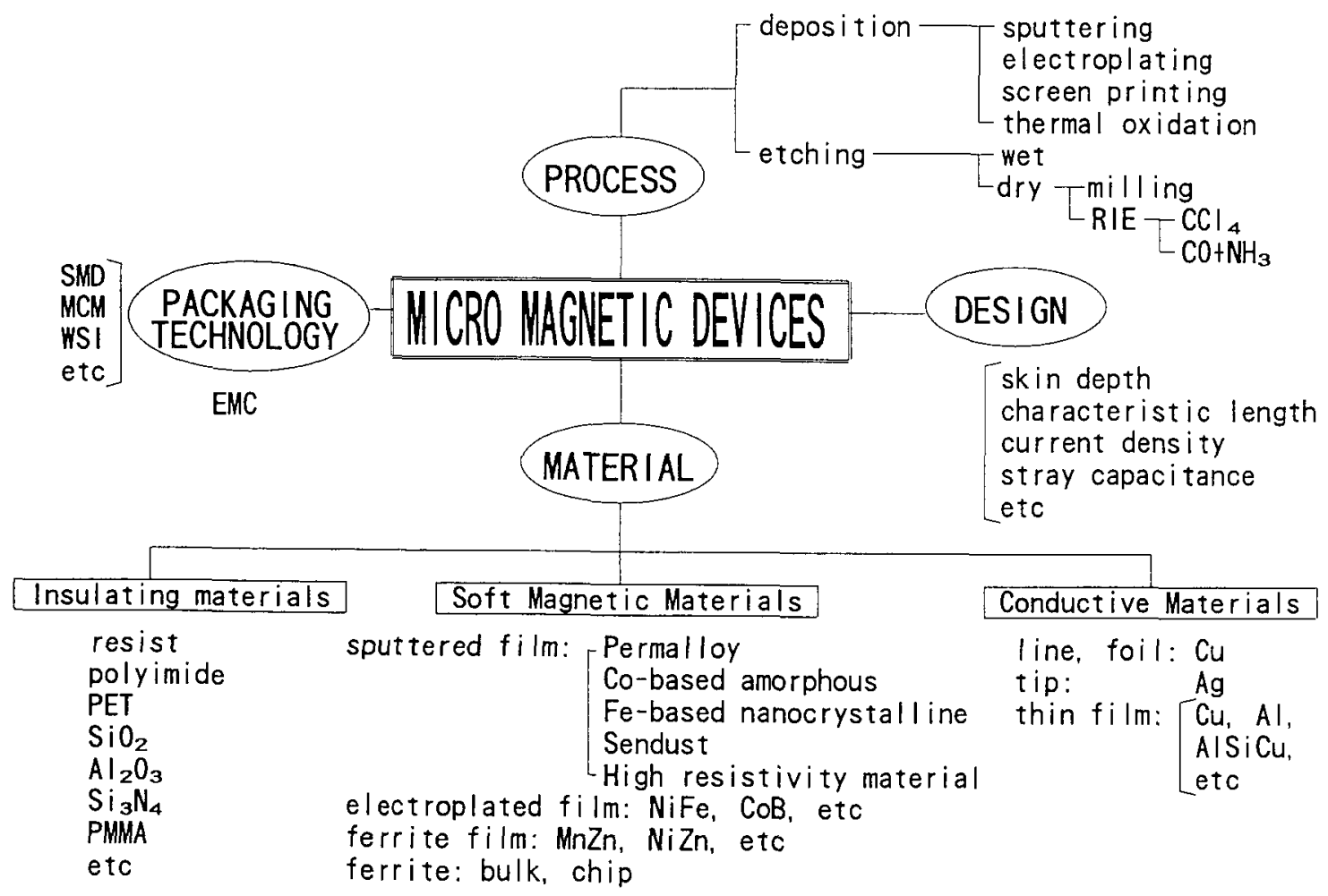

Fig. 1 Technology area of the micro magnetic devices. 
当面は厚膜微細加工にはフレームめっき法が不可欠と 思われる.

設計の中心は，微細構造の中で所望の磁束分布を得 る技術である. 電磁形マイクロ磁気デバイスの場合, とくに磁性膜の中に磁束を集中させ，漏れ磁束を最小 にするエ夫が重要であり，表皮梁さと特性長はその基 本パラメータである. 電源用マイクロ磁心などパワー 応用では磁心の電力密度が高いため, 設計上, 温度上 昇と磁束飽和の両方を考虑する必要がある。およそ $100 \mathrm{MHz}$ を越す高周波応用では金属磁性膜之導体層を電 極とするような漂遊容量を考虑し，磁心の使用帯域が LC共振で制限されないよう注意する.

実装上，薄膜磁心が単独で用いられることは少ない， フェライトチップのような表面実装部品，半導体集積 回路とのハイブリッドモジュール，さらには半導体集 積回路とモノリシックに集積化したMCM（Multi-Chip Module）など, 用途と実装技術の進展に合わせた方式 を選択する必要がある、これは作製プロセスやクロス トークなどの雑音問題にも関わる事項である.

Fig. 1には揭載していないが，高周波透磁率や磁心 の高周波特性計測など, 計測に関わる周辺技術も重要 である．また硬磁性薄膜材料の進展に期待が高い，個 別応用については文献1)〜20)を参照して頂きたい。

\section{3 マイクロ磁気アクチェエータの栕要}

ミリマシンの駆動力として電磁力が有用との考えは， 電磁力が寸法の3〜4乗に比例して変化するのに対し， 例えば静電力は2乗で変化するというスケーリング則に 基ついている，静電力，压電力，熱膨張など，従来か らマイクロマシンの駆動力として検討されているもの と比べた電磁駆動型並びに磁気駆動型の特徵を列挙す れば，以下の通りである.

（1）場の磁気エネルギーを利用することにより非接触 駆動が可能である.これにより電力供給線が不要とな るため，アクチュエータが軽量で楧造が简単になり， 微細加工も容易になる．更に，管内や真空装置内など にある可動部を外部から駆動・制御可能となるため新 規な応用分野の開発が可能となる。

（2）磁気アクチュエータは基本的に電流による磁界の エネルギーで駆動されるため, 電源からみると高速, 低インピーダンス，低電圧駆動となる，静電，圧電ア クチュエータが高速, 高インピーダンス，高電圧㽖動 であることと比へると，低電圧でよいことは設計上の 自由度を增し，パッケージングむ容易になる。
（3）以上をまとめて，駆動力や変位が大きく，実用的 なミリマシンの駆動方式として有用である.

（4）磁性体には，軟磁性材料，硬磁性材料，磁歪材料， 機能性磁性材料(磁気抵抗効果, 光磁気材料等)をはじ め，各種の薄膜ならびにバルク材料がある。これらを 利用することにより新規なデバイス，アクチュエータ の実現が可能と考えられる.

薄膜・厚膜を使用する以上，マイクロマシン・ミリ マシンの駆動力や変位はバルク材料を用いた小形機械 に比へて小さくなる．この小さな駆動力・変位を実用 に結実させるためのアプローチがマイクロマシン全般 の基本的問題である. これに対して, 光スキャナ, 光 フィルタなどの光応用と, マイクロバルブ，マイクロ リレーなどが現実性を帯びてきている．磁気駆動形マ イクロマシンの応用例は文献21) 36)を参照されたい. なお，マイクロマシン・ミリマシンの微細構造の中 に良質の磁性材料を製作し，その良さを生かして行く ためには，磁気研究者の参入と異分野の研究者之の有 機的な情報交換が不可欠と考えられている.

\section{4 高周波微小磁気回路の設計技術}

薄膜インダクタ，トランスにおける鎖交磁束量は磁 心体積から考えてバルク磁心に比へてて小さく，磁心と して必要なインピーダンスや電圧を確保するためには 高周波動作が必須となり，用途にもよるが1MHz 3GHz 程度が興味の対象となっている.コイルパターンは磁 化困難軸方向に磁性膜を励磁するように決定される．

100HHz以上の帯域では磁心のインダクタンスと漂遊 容量によるLC共振の影響が顕著になるが，それ以下の 周波数領域では磁性薄膜とコイル導体薄膜の表皮深さ， 並びに特性長が素子設計上の基本パラメータになって いる，低周波素子では膜厚を増加させ㧈ばインダクタ ンスが增加し，トランスでは結合係数が向上するため 厚膜化は設計上有用であるが，高周波領域では膜厚を 表皮厚さの約2倍以上に厚くしても単に渦電流を增加さ せるばかりで透磁率は低下し，素子特性は劣化する。 表皮深さ $\delta$ を式で表せば，

$$
\delta=(\rho / \pi \mu \mathrm{f})^{1 / 2}
$$

ただし， $\rho$ は抵抗率， $\mu$ は透磁率，fは周波数である.

Fig. 2 は代表的な薄膜材料の表皮深さを示す．周波 数を10MHzとすると，既知の軟磁性薄膜としては高抵抗

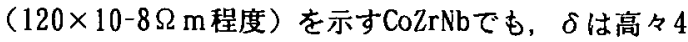


$\mu \mathrm{m}$ 程度である. 一方, 薄膜コイル材料として使用され

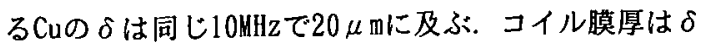
の $\pi / 2$ 倍の範围内 ${ }^{\left.3{ }^{8}\right)}$ で厚膜化し，低抵抗化することが 設計の基本である. したがって，およそ10 Hzz以下の低 周波帯域では，数 $\mu \mathrm{m}$ 厚の磁性薄膜と数 $10 \mu \mathrm{m}$ 厚のコ イルの組合せが可能になる.

次に，この膜厚条件が与えられると，コイルとコイ ルの隙間から磁束を漏洩させないための条件，すなわ 与特性長 ${ }^{40 ， 41)}$ によって許容しうる最大のコイル間隔 が決定される. Fig. 3は内部コイル形薄膜インダクタ における特性長入を説明したものである.

$$
\lambda=(\mu r \cdot t \cdot g)^{1 / 2}
$$

ただし， $\mu$ rは比透磁率，tは磁性薄膜の膜厚，gは上下 の磁性膜の間隔である。磁性薄膜の比透磁率を500〜 1000 程度の現実的な值と想定して，内部コイル形薄膜 インダクタについて必要とされるコイル間隔を計算す ると数 $\mu \mathrm{m}$ 以下のオーダとなる. 以上の考察は， 10 $\mu \mathrm{m}$ 以上の厚膜導体を数 $\mu \mathrm{m}$ 間隔で配置するような微細 加工技術や平坦化処理の必要性を示している. 現在実 用化が期待されている $1 \sim 10 \mathrm{MHz}$ 帯域用薄膜インダクタ はこの考え方に沿うものである.

なお，磁性膜のサイズが小さくなるとその透磁率が 変化する．Fig. 4はこれを説明したもの ${ }^{42)}$ で，磁性 層の総厚み $\mathrm{Tm}$ が $2 \mu \mathrm{m}$ の条件下では $\mathrm{tm}=0.1 \mu \mathrm{m}, \mathrm{ti}=0.05$ $\mu \mathrm{m}$ で薄膜インダクタのQに直接比例する材料パラメー

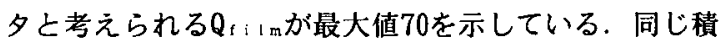
層構造でも膜サイズが $10 \mathrm{~mm} \times 20 \mathrm{~mm}$ の場合はQ $\mathrm{i}$ । $\mathrm{m}=3$ 以下 であり, 寸法効果が顕著である.

Fig. 5(a)は，薄膜インダクタ用の磁性膜パターンを 模した格子状Cullo-NiFe膜の構成を示している ${ }^{43)}$ 。同 図(b)は困難軸方向に励磁した場合の透磁率を示してい る. 実線, 破線, 一点鎖線は電磁界シミュレータ(MAG NA/FIM)による計算値，O印は実験值である．試料はス パッ夕製膜後にイオンミリングによって所期の形状と した，微細加工前の比透磁率は1500である．単位格子 が孤立している場合は，一点鎖線で示したように反磁 界によりみかけの比透磁率は100に低下する．逆にすへ ての格子を間隔零で集合させたとすると，破線のよう に微細加工前の比透磁率にほほ等しい値が得られると 計算される．単位格子の間隔 $\mathrm{d}$ 稀十分大きい場合は孤 立格子の比透磁率に漸近し，間隔が十分小さい場合は 集合格子の比透磁率まで增大する．実驗結果も計算値
に一致している．以上の結果は直感的にも理解される 事項であるが，微細構造中の分布磁束の制御及びデバ イス特性の設計上は定量的に把握する必要のある事項 でもある．現状では数值計算に頼っているが，簡素な 計算モデルが開発されると設計, 解析上きわめて有用 である.

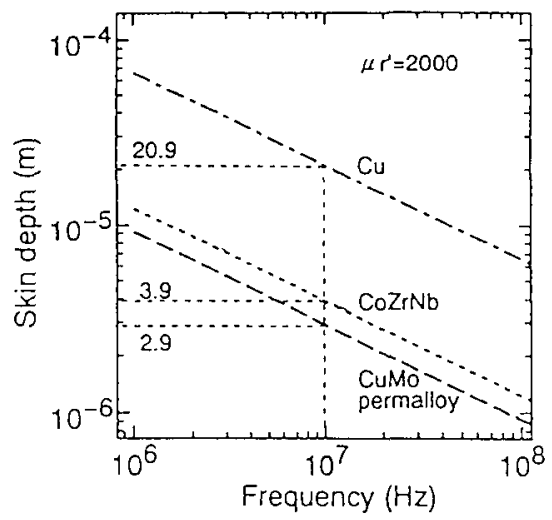

Fig. 2 Skin depth of metallic films.

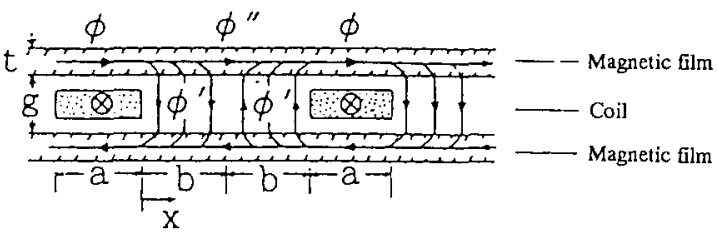

Fig. 3 Characteritic length of flux flow.

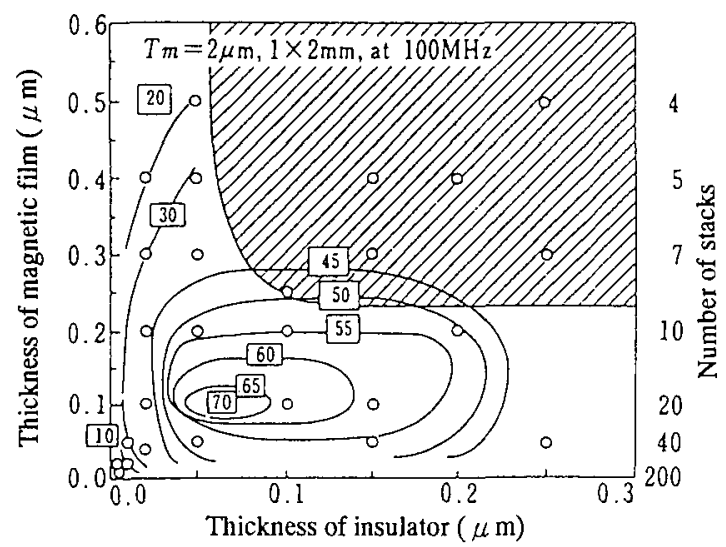

Fig. 4 Relation between the dimension and permeability for CoFeSiB/SiO2 stacked film. 


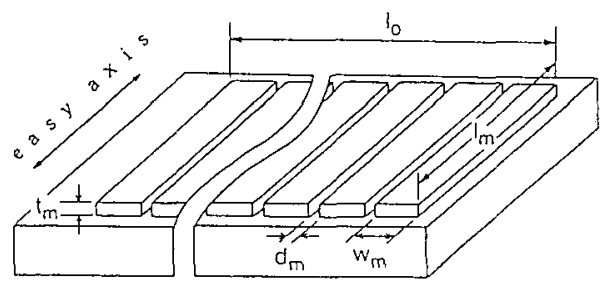

(a) Slitted film structure

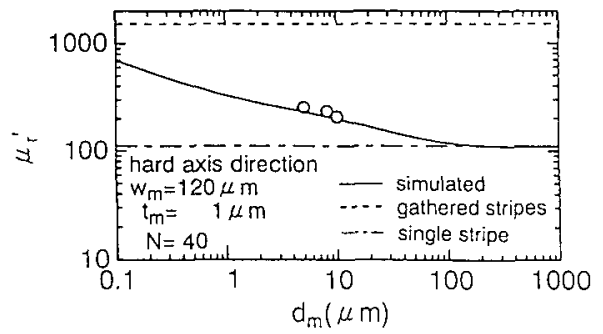

(b) Permeability

Fig. 5 Apparent permeability of the slitted CuMo-NiFe film.

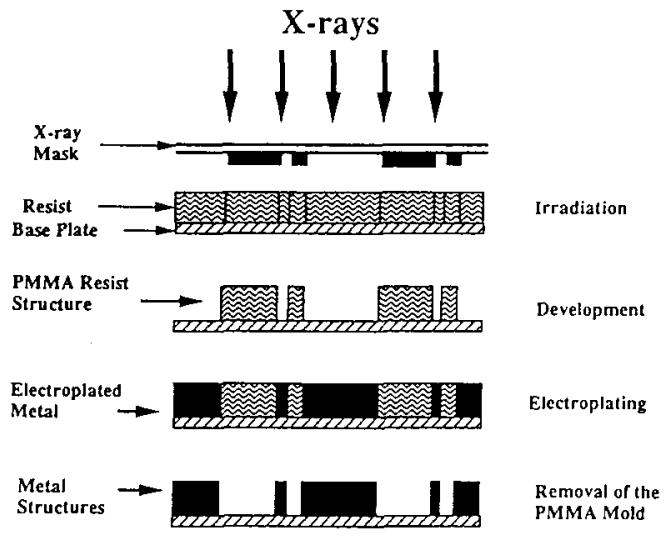

Fig. 6 Schematic explanation of LIGA process ${ }^{45}$.

\section{5 厚绰微耕加工技術}

Fig. 6 は, LIGAプロセスと呼ばれる厚膜微細構造形 成法を示したものである ${ }^{44)}$ ，基板上に電気めっき用の 種層を製膜した後にPMHAを付与し，シンクロトロン放 射光とX線マスクによって近接簬光し，現像してめっき フレームを得る. 次に電気めっきによってフレームを 満たして厚膜微細潔造を形成し，PHMAを除去して完成
される. 数 $100 \mu$ 泎及ぶ厚膜微細構造が形成可能な点 が特徵であるが，放射光を得るための設備とX線マスク が必要なため簡単には導入できない，当初は直径数 $\mathrm{km}$ に及ぶ放射光リングの一部から微細加工用の線源を得 ていたが, 最近では直径数盺小形の設備も開発されて いる.

放射光を使用せず，一般的な紫外線露光によっても $100 \mu \mathrm{m}$ 程度までの厚膜構造を得ることが可能で, 多く の報告が行われている. 更に最近，Alの陽極酸化によ る立体的微細加工法が報告された 条件下でAlを陽極酸化すると表面に直径数 $10 \mathrm{~nm}$ ，深さ $100 \mu \mathrm{m}$ 程度のポアが数 $\mu \mathrm{m}$ 間隔でほぼ均一に形成できる ことを利用したすので，陽極酸化後の表面にレジスト を塗布し紫外線露光によってレジス卜をパ夕ーニング した後,ウェットエッチングによって隣接ポアが接触 するまで極端にポアを拡大させると，レジストパター ンのない部分がおよそポアの深さまで除去されるとい

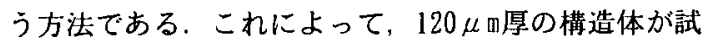
作されている.

\section{6 まとめ}

マイクロ磁気デハイス, マイクロ磁気アクチュエー 夕の開発状況亡これを支える厚膜微細加工技術につい て概説した． 紙面の都合でデバイス・アクチュエータ の実例を直接紹介できなかったので，文献を参照して いただきたい．

\section{文 献}

1) 応用磁気セミナー「携帯機器への磁気応用」 1995 .

2) N. Saleh, A. H. Qureshi, ELECTRONICS LETTERS 31st December 1970 No. 6 (1970) 850.

3) K. Kawabe, H. Koyama, K. Shirae, IEEE Trans. Magn., MAG-20 (1984) 1804.

4）浅田規裕，松木英敏，江刺正喜，電学論 A-114 (1994) 53.

5) T. Nishikawa, IEICE TRANS. 74 (1991) 1556.

6) TDKカタログ, CATALOG №. CVJ-005B(1994).

7) Y. Hamasaki, T. Ide, Transducers' 95 and Euro sensors IX (1995) 265-A10.

8) N. Asada, H. Matsuki, K. Minami, M. Esashi, IEEE Trans. Magn., 30 (1994) 4647.

9) H. Ota, T. Oda, M. Kobayashi, MEMS 95 (1995) 197.

10) T. Sato, H. Tomiya, A. Sawabe, T. Inoue, T. Mizoguchi, M. Sahashi", IEEE Trans. Magn., 30 (1994) 217.

11）三野，塚本，谷内，柳沢，田子, 電気学会マグネ ティックス研究会 (1994) MAG-94-191.

12）西島, 日高, 斎藤, 山沢, 信学論 C-II, J78-C-II 
(1995) 339.

13) C. R. Sullilvan, S. R. Sanders, 1995 Power Electronics Specialists Conference (PESC'95) Record (1995) 658.

14)三野，塚本，柳沢，田子，谷内, 電気学会全国大会, (1995) 508 .

15) S. Kawahito, H. Satoh, M. Sutoh and Y. Tadokoro, Transducers' 95 and Eurosensors IX (1995) 290- 112 .

16）中西，吉見，務中，飯岛，山田, 電気学会全国大会, (1995) 483.

17) R. Gottfried-Gottfried, W. Budde, R. Jahne, H. Kuck, B. Sauer, S. Ulbricht, U. Wende, Transducers' 95 and Eurosensors IX (1995) 289 $-\mathrm{A} 12$.

18）高山, 鉿木, 丹羽, 日本応用磁気学会誌, 17(1993) 227.

19）斎藤，長谷，若宮，電気学会全国大会，(1993)1827.

20）面実装電子部品力タログ, TDK EVJ-001K (1994).

21) H. Inoue, N. Fujita, T. Fujii", J. Appl. Phys., 73 (1993) 6159.

22）内山，毛利，神保，綱島，日本応用磁気学会誌，19 (1995) 481.

23) H. Guckel, T. R. Christensen, K. J. Skrobis, T. S. Jung, J. Klein, K. V. Hartojo, I. Widjaja, MEMS 93 (1993) 7.

24) B. Wagner, M. Kreutzer, W. Benecke, J.Microelectromechanical Systems, 2 (1993) 23.

25) M. G. Allen, Transducers ' 93 (1993) 60.

26）伊東，日本応用磁気学会誌，18(1994) 922.

27) K. Yanagisawa, H. Kuwano, A. Tago, Transducers ' 93 (1993) 102.

28) H. Hosaka, H. Kuwano, MEMS 94 (1994) 313.

29) E. Hashimoto, H. Tanaka, Y.Suzuki, Y. Uenishi, A. Watabe, MEMS 94 (1994) 108.
30) C. H. Ahn, M. G. Allen, MEKS 94 (1994) 91.

31) C. H. Ahn, H. G. Allen, MEMS 95 (1995) 408.

32) T. R. Ohnstein, J. D. Zook, J. A. Cox, B. D. Speldrich, T. J. Wagner, H. Guckel, T. R. Christenson, J. Klein, T. Earles, I. Glasgow, MEHS 95 (1995) 170.

33) F. Cardot, J. Gobet, M. Bogdanski, F. Rudolf, Transducers ' 93 (1993) 32.

34）本田, 荒井, 菅原, 石山, 山口, 日本応用磁気学会 誌, 19 (1995) 501 .

35) K. I. Arai, W. Sugawara, T. Honda, Transducers ' 95 and Eurosensors XI (1995) 316.

36) T. Honda, K. I. Arai, M. Yamaguchi, J. Appl. Phys., 76 (1994) 6994.

37) E. Quandt B. Gerlach, K Seemann", J. Appl. Phys., 76 (1994) 7000.

38) E. Quandt, K.Seemann, MEMS 95. (1995) 273.

39) 榊原, 信学論 J73-B-1 (1991) 618 .

40) R. E. Jones, IEEE Trans. Magn., MAG-14 (1978) 509.

41) 白江, 電気学会全国大会シンポジウム (1990) S. 18-1.

42）白川, 倉田, 野瀬, 三寺, 中島, 村上, 電気学会 マグネティックス研究会 (1993) MAG-93-265.

43) V. Yamaguchi, A. Arakawa, K. I. Arai, F. Kumagai, S. Kikuchi, IEEE Trans. Magn., 29 (1993) 5210.

44) W. Ehrfeld, Micro System Technologies 90 (1990) 521.

45) A. B. Frazier, M. G. Allen, J. Microelectromechanical Systems, 2 (1993) 87.

46) S. Tan, H. Reed, H. Han, R. Boudreau, MEMS 95 (1995) 267.

47）日本応用磁気学会誌，18（1994）895. 